\title{
Effects of Malaria on Iron Stores in the Pregnant Women of Buea and Tiko Health District, South West Region, Cameroon
}

\section{Nfor O Nlinwe*}

Department of Medical Laboratory Science, University of Bamenda, Cameroon

\begin{abstract}
Malaria infection has a complex effect on iron metabolism that may affect the interpretation of haemoglobin, serum ferritin, serum transferrin and serum iron. The main objective of this study was to determine the effect of malaria parasitaemia on the iron store forms of pregnant women in the Buea and Tiko health districts of the S.W Region of Cameroon. This investigation was carried out from the $3^{\text {rd }}$ of August 2011 to the $30^{\text {th }}$ of April 2012 . The non-probabilistic sampling method was used to recruit a total of 377 pregnant women into the study. Questionnaires were used for the collection of secondary data. The microscopy method was used to detect the presence of malaria infection. A total of $41.4 \%$ (156/377) of the pregnant women were infected with Plasmodium falciparum. Of the infected cases; $32.1 \%$ had low levels of serum ferritin $(<20 \mu \mathrm{g} / \mathrm{L}), 10.9 \%$ had high levels of serum transferrin $(>360 \mathrm{mg} / \mathrm{dl})$, and $45.5 \%$ had low levels of serum iron $(<9.0 \mu \mathrm{mol} / \mathrm{l})$. The quantitative results using regression analysis justified that $88 \%$ variation in serum ferritin, transferrin and iron were accounted for by variation in malaria parasitaemia during the second and the third trimesters. Serum iron, ferritin and transferrin measurements should be incorporated as one of the routine laboratory tests during the regular antenatal care visits.
\end{abstract}

Keywords: Anaemia; Pregnancy; Low birth weight; Malaria; Cameroon

\section{Introduction}

Severe anaemia in pregnancy is an important direct and indirect cause of maternal death, and for the foetus, severe maternal anaemia may result in intra-uterine growth retardation, stillbirth and low birthweight [1,2]. Malaria infection has a complex effect on iron metabolism that may affect the interpretation of haemoglobin, serum ferritin, serum transferrin and serum iron [1].

In 1999, a special symposium entitled "Improving Adolescent Iron status before childbearing" was convened in Washington D.C. The resolution adopted from the symposium was that, emphasis needs to be placed on pre-pregnancy programmes to increase body iron stores [3]. In spite of this, severe anaemia continues to increase the risk for maternal mortality. Worse of all, malaria anaemia is estimated to affect up to 16 million women and children by the year 2015 [4]. In September 2000, the largest gathering of world leaders in human history convened for the Millenium Summit on the Millenium Development Goals (MDGs) in which a plan was adopted to achieve eight anti-poverty goals by the year 2015. As one of the steps to achieving the goals, stakeholders committed 40 billion US dollars in resources to a global effort to save the lives of the 16 million women and children who are likely to be affected by malaria induced anaemia by the year 2015 .

In line with the MDG, this work was designed to investigate into the insidious effect of malaria on the iron stores of the pregnant women in Buea and Tiko Health Districts of the Fako Division in the South West Region of Cameroon. In order to achieve this objective, attempts will be made to answer the following question:

What is the insidious effect of malaria on the iron status of the pregnant women in the Buea and Tiko Health Districts?

\section{Materials and Methods}

\section{Study area}

The study was conducted in the Buea and Tiko Health Districts located in the Fako division of the South West Region of Cameroon. Both districts are located between Longitude $8.6^{\circ} 10^{\prime} \mathrm{E}$ and Latitude $4^{\circ} 5.2^{\prime} \mathrm{N}$. The climate alternates from the hot humid coastline, the Tiko plain, to the temperate climate on the mountain slopes where Buea is situated [4].

The mount Cameroon region is hyper-endemic for malaria, with Plasmodium falciparum being the predominant malaria parasite species [5]. Fako division is divided into four health districts; Buea, Limbe, Muyuka and Tiko Health District. In these health districts, there are health units, district hospitals and a regional hospital which offer services of antenatal care to pregnant women. The inhabitants of this region are of the English speaking Cameroonians and their occupations vary from farmers, business personnel and public servants.

\section{Ethical clearance}

Ethical Clearance and authorization to collect specimens for this research was obtained from the Ethical Committee Board of the Ministry of Public Health, Regional Delegation for the South West Region, Cameroon. Informed consent was handed to the prospective research subjects on recruitment.

\section{Experimental design}

Sample size determination: The sample size for this work was determined based on the Yaro Yamane's approach for finite population [6]. This was made possible by using the formula;

$$
\begin{aligned}
& \mathrm{n}=\mathrm{N} / 1+\mathrm{N}(\mathrm{e})^{2} \\
& \text { Where; } \\
& \mathrm{n}=\text { the expected sample size, }
\end{aligned}
$$

*Corresponding author: Nfor O Nlinwe, Department of Medical Laboratory Science, University of Bamenda, Cameroon, Tel: +237-70222093/ +237-91820090; E-mail: omarinenlinwe@yahoo.ca

Received November 03, 2014; Accepted November 24, 2014; Published November 26, 2014

Citation: Nlinwe NO (2014) Effects of Malaria on Iron Stores in the Pregnant Women of Buea and Tiko Health District, South West Region, Cameroon. J Metabolic Synd 3: 170. doi:10.4172/2167-0943.1000170

Copyright: @ 2014 Nlinwe NO. This is an open-access article distributed under the terms of the Creative Commons Attribution License, which permits unrestricted use, distribution, and reproduction in any medium, provided the original author and source are credited. 
$\mathrm{N}=$ the finite population out of which the sample was drawn.

$e=$ the level of significance (or limit of tolerable error) [6].

For this work, the estimated population size (N) from the 2010 population statistics was 11047 [7] (Regional Delegation of Public Health, SW Region, 2010), and the level of significance (e) is 0.05 or $5 \%$. So:

Estimated Sample Size $=11047 / 1+11047(0.05)^{2}$

$$
=11047 / 28.6175 \approx 386
$$

From the above calculation, the estimated sample size was 386 pregnant women. To make for attrition, a total of 482 pregnant women were recruited for this study, from five different centres.

Scope of study: This cohort (longitudinal) study recruited pregnant women at the time of registration for antenatal care visits. This intensive field research was carried out within a period of nine months, from the 3rd of August 2011 to 30th of April 2012.

Population sampled: Samples were drawn from the Cameroon Development Coorperation (CDC) Central Clinic Tiko (CCT), Mutengene Baptist Hospital (MBH), Buea Regional Hospital (BRH), Government Health Center Muea (GHCM) and the Buea Road Integrated Health Center (BIH). Newly registered pregnant women for antenatal clinic were considered eligible for recruitment as research participants. The sampling method which was used was the nonprobabilistic sampling method, the volunteer sampling technique.

Administration of questionnaire: Newly registered pregnant women for antenatal care visits (whose pregnancies were from the second trimester and below), were contacted on one-to-one basis and after a brief description of the study, the informed consent was handed to them. The consent form was signed by those who have read and understood the informed consent. The questionnaire was filled by those who signed the consent forms. And all those who filled the questionnaires were recruited into the study.

\section{Laboratory diagnostic methods}

All the medical laboratory diagnostic tests were carried out in the teaching laboratory of the Faculty of Health Sciences, University of Buea.

Parasitological examination: The parasitological examination was carried out once during the second trimester and once during the third trimester, for each pregnant woman. Capillay blood was collected from the finger prick and was used to prepare both the thin and the thick blood films. The blood films were air-dried and the thin blood film fixed with absolute methanol for one to two minutes. The blood films were then stained with $3 \%$ Giemsa staining solution, for 30 minutes. Buffered water was used to flush the stain from the slide, to avoid the films being covered with fine deposit of stain and the stained films were air-dried.

\section{Examination and determination of malaria parasite density:}

Thick Film: The dried slides were mounted and examined using the high power 100x objective lens. Thick blood films were used to detect the presence of Plasmodium sp and the level of parasitaemia, while thin blood films were examined to determine speciation. Parasite counting was done by counting the number of parasites against at least 100 leukocytes, or 200 leukocytes for the definitive count. The number of the parasites counted was calculated using the formula:

$$
\text { Parasites } / \mu \text { l of blood }=\frac{\text { Number of parasites counted } \times 8000 \text { leukocytes }}{\text { Number of WBC Counted }}
$$

For the positive cases, parasitaemia was classified as follows:

1-999 Parasites $/ \mu$ of blood $=$ Mild parasitaemia.

1,000-9,999 Parasites $/ \mu$ l of blood = Moderate parasitaemia.

$\geq 10,000$ Parasites $/ \mu$ l of blood $=$ Severe parasitaemia [8]

Measurement of serum ferritin: The quantitative determination of serum ferritin was carried out using reagents produced by Fortress Diagnostics ISO 13485 accredited company, United Kingdom. The spectrophotometric method of measurement was employed (Batch number: BXCO441A). The calibration curve was drawn by preparing serial dilutions of the calibrator using $\mathrm{NaCl} 9 \mathrm{~g} / \mathrm{L}$ as diluents. The concentration of the calibrator was multiplied by the corresponding factor, as indicated on the manufacturer's guide (Fortress Diagnostics ISO 13485 Accredited Company), to obtain the ferritin concentration of each point on the curve.

The reagents for this measurement were allowed to come to room temperature and then pipette into test tubes following the manufacturer's guide (Fortress Diagnostics ISO 13485 Accredited Company).

The contents in the test tubes were well mixed and the absorbance read and recorded immediately as A1. The absorbance was read again after 8 minutes of incubation at $37^{\circ} \mathrm{C}$ and recorded as $\mathrm{A} 2$. The absorbance difference (A2-A1) at each point of the curve was calculated and the values obtained were plotted against the ferritin concentration for each calibrator dilution. The ferritin concentration in the sample was then read from the intercept point (A2-A1) on the calibration curve.

Measurement of serum transferrin: The quantitative determination of serum transferrin was carried out using reagents produced by Fortress Diagnostics Company ISO 13485 Accredited Company. The spectrophotometric method of measurement was employed. (Batch number: BXCO741A)

Six levels of standards which accompanied the test kit had their calibrator values or concentrations labelled on it. After bringing them to room temperature, calibrators/samples, alongside with the reagents were pipetted into test tubes, following the manufacturer's guide (Fortress Diagnostics ISO 13485 Accredited Company).

The change of absorbance $\left(A_{2}-A_{1}\right)$ was calculated. A graph using the concentrations of the six levels of standards against its absorbance $\left(\mathrm{A}_{2}-\right.$ $\left.A_{1}\right)$ was drawn. The concentration of transferrin in patient sera was read from the graph using its change of absorbance $\left(\mathrm{A}_{2}-\mathrm{A}_{1}\right)$ values.

Measurement of serum iron: The quantitative determination of serum iron was carried out using reagents produced by Fortress Diagnostics ISO 13485 Accredited Company, United Kingdom and the spectrophotometric method of measurement was employed. (Batch number: BXCO236A)

The reagents were pipette into test tubes following the manufacturer's guide (Fortress Diagnostics ISO 13485 Accredited Company).

The contents in the pipettes were mixed and incubated for 10 minutes at $37^{\circ} \mathrm{C}$. The absorbance of the samples and the standards were read against the reagent blank. The iron concentrations in $\mu \mathrm{mol} / \mathrm{L}$ were then calculated as follows:

Absorbance of Sample $\times$ Standard concentration $=$ Sample Concentrations $(\mu \mathrm{mol} / \mathrm{L})$ Absorbance of Calibrator 


\section{Data analysis}

Descriptive statistics (mean, median and mode), with the use of tables were employed in the presentation of results on age, marital status, occupation, gravidity and iron supplementation. The multiple regression analysis was used to justify a strong goodness of fit for the effect of malaria on serum ferritin, transferrin and iron in the study subjects, for the five centres of the study area.

\section{Results}

The status of malaria infection in the study area by centers is shown in Figure 1. Malaria endemicity in the study area by trimester is shown on Figure 2. The levels of parasitaemia in the entire study area by trimesters are shown on Table 1. The status of malaria infection in the study area by age, marital status, occupation, gravidity and iron supplementation in the study area is shown on Table 2. Variation of serum ferritin, transferrin, iron and WBC among the pregnant women

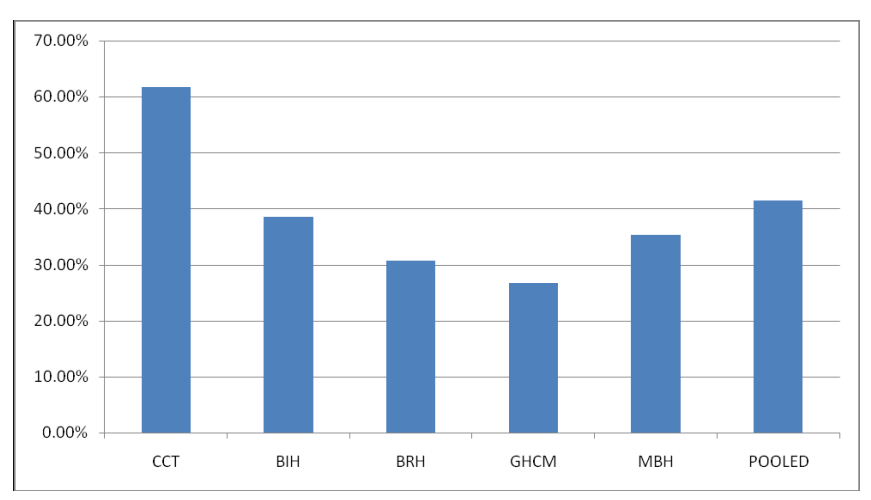

CCT = CDC Central Clinic Tiko, BIH = Buea Road Integrated Health Centre $\mathrm{BRH}=$ Buea Regional Hospital, $\mathrm{GHCM}=$ Government Health Centre Muea, $\mathrm{MBH}=$ Mutengene Baptist Hospital

Figure 1: The status of malaria infection in the study area by centers.

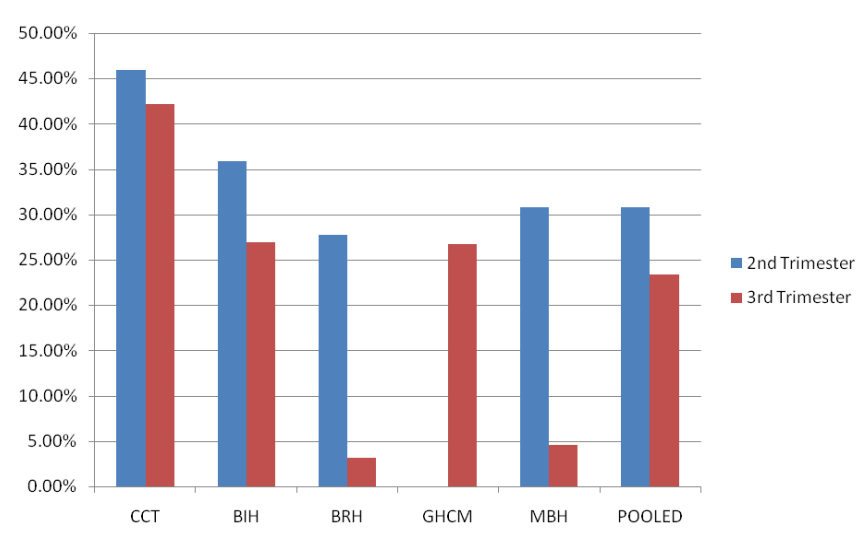

Figure 2: Malaria endemicity in the study area by trimester.

\begin{tabular}{|c|c|c|c|c|}
\hline Trimester & $\begin{array}{c}\text { Mild } \\
\text { Parasitaemia (\%) }\end{array}$ & $\begin{array}{c}\text { Moderate } \\
\text { Parasitaemia (\%) }\end{array}$ & $\begin{array}{c}\text { Severe } \\
\text { Parasitaemia (\%) }\end{array}$ & Total (\%) \\
\hline First & - & - & - & - \\
\hline Second & $57(49.1)$ & $54(46.6)$ & $05(4.3)$ & $116(56.9)$ \\
\hline Third & $49(55.7)$ & $36(40.9)$ & $03(3.1)$ & $88(43.1)$ \\
\hline Total & $106(52.0)$ & $90(44.1)$ & $08(03.9)$ & $204(100)$ \\
\hline
\end{tabular}

Table 1: Mild Parasitaemia = 1-999 trophozoites $/ \mu \mathrm{L}$ of blood; Moderate Parasitaemia $=1,000-9,999$ trophozoites $/ \mu \mathrm{L}$ of blood; Severe Parasitaemia $=$ $\geq 10,000$ trophozoites/ $\mu \mathrm{L}$ of blood (WHO, 2003).

\begin{tabular}{|l|c|c|c|}
\hline Parameters & & $\begin{array}{c}\text { No Examined } \\
(\%)\end{array}$ & $\begin{array}{c}\text { No Infected } \\
(\%)\end{array}$ \\
\hline Age & $15-25 y r s$ & $165(43.8)$ & $63(38.2)$ \\
\hline Marital Status & $26-35 y r s$ & $190(50.4)$ & $83(43.7)$ \\
\hline & $36-45 y r s$ & $22(05.8)$ & $10(45.5)$ \\
\hline & Married & $266(70.6)$ & $116(43.6)$ \\
\hline Occupation & Single & $111(29.4)$ & $40(36.0)$ \\
\hline & House wives & $143(37.9)$ & $61(42.7)$ \\
\hline Gravidity & Sublic Servants & $81(21.5)$ & $47(58.0)$ \\
\hline & Farmers & $19(05.0)$ & $05(26.3)$ \\
\hline Iron & Bussiness personelle & $88(23.3)$ & $37(42.1)$ \\
\hline Supplementation & Multigravidae & $264(70.0)$ & $109(41.3)$ \\
\hline Total for each Parameter & Primigravidae & $113(30.0)$ & $47(41.6)$ \\
\hline
\end{tabular}

Table 2: The status of malaria infection in the study area by age, marital status, occupation, gravidity and intake of iron supplementation, in the study area.

is shown on Table 3. The variation of serum ferritin, transferrin, iron and WBC among pregnant women infected with malaria, by study centers is shown on Table 4. The quantitative regression result on the effect of malaria on serum ferritin, transferrin and iron by trimesters is shown on Table 5.

\section{Discussion}

In this study $41.4 \%(156 / 377)$ of the research participants were infected at least once, in their second and/or third trimester of pregnancy. This study, carried out in an area previously described as being hyper endemic for malaria reported a high percentage of malaria $(41.4 \%)$ as expected. This is in agreement with the findings reported by Meeusen et al. that pregnant women in endemic areas are highly susceptible to malaria $[5,9]$. This is also in agreement with the work of Achidi et al. carried out in the Mutengene Maternity, in the South West Region of Cameroon, which reported a $44.7 \%$ rate of malaria infection among pregnant women, at the point of antenatal enrolment [10]. The findings agrees with that reported for Kassena-Nankana district of Ghana in which, the overall prevalence of malaria parasitaemia during pregnancy was $47 \%$, out of 3642 pregnant women of all gravidities and gestational age of 18-32 weeks [11].

Malaria demonstrated insidious influence on SF, ST and SI stores during the period of study, as the goodness of fit value the adjusted R2 was $88 \%$, meaning that $88 \%$ variation in SF, ST and SI was accounted for by the presence of malaria in the study area. The value of R2 which gives information about the inclusive and non-inclusive variables has therefore demonstrated that, the inclusive variable (malaria) had an insidious effect on SF, ST and SI. The non-inclusive variable which could be considered as control includes those variables which were not measured, which accounted for $22 \%$ variation in SF, ST and SI in the malaria positive cases. These variables could possibly include: Malaria in the first trimester, intestinal helminthic and protozoan infections associated with anaemia, variation in the physiological response to changes induced by pregnancy, variation in the nutritional content of food intake.

This results equally revealed that $1 \%$ increase in trophozoites/ul of blood in the second trimester insidiously accounted for $0.17 \%$ percent decrease in serum ferritin in CCT $(\mathrm{P} \leq 0.01), 0.14 \%$ percent decrease in serum ferritin in $\mathrm{BIH}, 0.46 \%$ percent decrease in serum ferritin in $\mathrm{MBH}$ and $0.19 \%$ percent decrease in serum ferritin in BRH $(\mathrm{P} \leq 0.01)$. These 


\begin{tabular}{|c|c|c|c|c|c|c|c|c|c|c|c|c|}
\hline $\begin{array}{l}\text { Status of } \\
\text { Infection }\end{array}$ & $\begin{array}{c}\text { No Examined } \\
(\%)\end{array}$ & $\begin{array}{c}\text { Low SF } \\
(\%)\end{array}$ & $\begin{array}{c}\text { Normal SF } \\
(\%)\end{array}$ & $\begin{array}{c}\text { High SF } \\
(\%)\end{array}$ & $\begin{array}{c}\text { Low ST } \\
(\%)\end{array}$ & $\begin{array}{l}\text { High ST } \\
(\%)\end{array}$ & $\begin{array}{c}\text { Low SI } \\
(\%)\end{array}$ & $\begin{array}{c}\text { Normal SI } \\
(\%)\end{array}$ & $\begin{array}{c}\text { High SI } \\
(\%)\end{array}$ & $\begin{array}{c}\text { Low WBC } \\
(\%)\end{array}$ & $\begin{array}{c}\text { Normal WBC } \\
(\%)\end{array}$ & $\begin{array}{c}\text { High WBC } \\
(\%)\end{array}$ \\
\hline Infected & $\begin{array}{c}156 \\
(41.4)\end{array}$ & $\begin{array}{c}50 \\
(32.1)\end{array}$ & $\begin{array}{c}99 \\
(63.5)\end{array}$ & $\begin{array}{c}07 \\
(04.5)\end{array}$ & $\begin{array}{c}139 \\
(89.1)\end{array}$ & $\begin{array}{c}17 \\
(10.9)\end{array}$ & $\begin{array}{c}71 \\
(45.5)\end{array}$ & $\begin{array}{c}78 \\
(50.0)\end{array}$ & $\begin{array}{c}07 \\
(04.5)\end{array}$ & $\begin{array}{c}24 \\
(15.4)\end{array}$ & $\begin{array}{c}123 \\
(78.9)\end{array}$ & $\begin{array}{c}09 \\
(05.7)\end{array}$ \\
\hline Non-infected & $\begin{array}{c}221 \\
(58.62)\end{array}$ & $\begin{array}{c}71 \\
(32.1)\end{array}$ & $\begin{array}{c}135 \\
(61.1)\end{array}$ & $\begin{array}{c}15 \\
(06.8)\end{array}$ & $\begin{array}{c}197 \\
(89.1)\end{array}$ & $\begin{array}{c}24 \\
(10.9)\end{array}$ & $\begin{array}{c}85 \\
(38.5)\end{array}$ & $\begin{array}{c}127 \\
(57.5)\end{array}$ & $\begin{array}{c}9 \\
(04.1)\end{array}$ & $\begin{array}{c}39 \\
(17.7)\end{array}$ & $\begin{array}{c}169 \\
(76.5)\end{array}$ & $\begin{array}{c}13 \\
(05.9)\end{array}$ \\
\hline Total & 377 & $\begin{array}{c}121 \\
(32.1)\end{array}$ & $\begin{array}{c}234 \\
(62.1)\end{array}$ & $\begin{array}{c}22 \\
(05.8)\end{array}$ & $\begin{array}{c}336 \\
(89.1)\end{array}$ & $\begin{array}{c}41 \\
(10.9)\end{array}$ & $\begin{array}{c}156 \\
(41.4)\end{array}$ & $\begin{array}{c}205 \\
(54.4)\end{array}$ & $\begin{array}{c}16 \\
(04.2)\end{array}$ & $\begin{array}{c}63 \\
(16.7)\end{array}$ & $\begin{array}{c}292 \\
(77.5)\end{array}$ & $\begin{array}{c}22 \\
(05.8)\end{array}$ \\
\hline
\end{tabular}

Table 3: SF=Serum Ferritin, ST=Serum Transferrin and SI=Serum Iron, WBC = White blood cell count Low SF $=<20$ ug/), Normal SF $=20-200$ ug/l, HighSF $=>200$ ug/l, Low ST $=<200 \mathrm{mg} / \mathrm{dl}$, Normal ST $=200-360 \mathrm{mg} / \mathrm{dl}$, High ST $=>360 \mathrm{mg} / \mathrm{dl}$, Low SI $=<9.0 \mathrm{umol} / \mathrm{l}, \mathrm{Normal} \mathrm{SI}=9-30.4 \mathrm{umol} / \mathrm{l}, \mathrm{High} \mathrm{SI}=>30.4 \mathrm{umol} / \mathrm{l}, \mathrm{Low} \mathrm{WBC}=<4 \times 10^{9} / \mathrm{l}$, Normal WBC $=4.0-10.0 \times 10^{9} / \mathrm{l}$, High WBC $=>10.0 \times 10^{9} / \mathrm{l}$ (Fortress Diagnostics ISO 13485 Accredited Company). Normal ST was not recorded.

\begin{tabular}{|c|c|c|c|c|c|c|c|c|c|c|c|c|}
\hline $\begin{array}{l}\text { Research } \\
\text { Center }\end{array}$ & $\begin{array}{c}\text { No Infected } \\
(\%)\end{array}$ & $\begin{array}{c}\text { Low SF } \\
(\%)\end{array}$ & $\begin{array}{c}\text { Normal SF } \\
(\%)\end{array}$ & $\begin{array}{l}\text { High SF } \\
(\%)\end{array}$ & $\begin{array}{c}\text { Low ST } \\
(\%)\end{array}$ & $\begin{array}{c}\text { High ST } \\
(\%)\end{array}$ & $\begin{array}{c}\text { Low SI } \\
(\%)\end{array}$ & $\begin{array}{c}\text { Normal SI } \\
(\%)\end{array}$ & $\begin{array}{c}\text { High SI } \\
(\%)\end{array}$ & $\begin{array}{c}\text { Low WBC } \\
(\%)\end{array}$ & $\begin{array}{l}\text { Normal } \\
\text { WBC (\%) }\end{array}$ & $\begin{array}{c}\text { High WBC } \\
(\%)\end{array}$ \\
\hline CDC Tiko & $\begin{array}{c}67 \\
(61.5)\end{array}$ & $23(34.3)$ & $40(59.7)$ & $04(06.0)$ & $06(91.0)$ & $06(09.0)$ & $35(52.2)$ & $28(41.80)$ & $04(06.0)$ & $12(17.9)$ & $52(77.6)$ & $03(04.5)$ \\
\hline BRH & $\begin{array}{c}20 \\
(30.8)\end{array}$ & - & $20(100)$ & - & $20(100)$ & - & $\begin{array}{c}10 \\
(50.0)\end{array}$ & $\begin{array}{c}10 \\
(50.0)\end{array}$ & - & $\begin{array}{c}07 \\
(35.0)\end{array}$ & $\begin{array}{c}13 \\
(65.0)\end{array}$ & - \\
\hline BIH & $\begin{array}{c}30 \\
(38.5)\end{array}$ & $\begin{array}{c}11 \\
(36.7)\end{array}$ & $\begin{array}{c}19 \\
(63.3)\end{array}$ & - & $\begin{array}{c}25 \\
(83.3)\end{array}$ & $\begin{array}{c}05 \\
(16.7)\end{array}$ & $\begin{array}{c}13 \\
(43.3)\end{array}$ & $\begin{array}{c}17 \\
(56.7)\end{array}$ & - & $\begin{array}{c}05 \\
(16.7)\end{array}$ & $\begin{array}{c}25 \\
(83.3)\end{array}$ & - \\
\hline GHCM & $\begin{array}{c}16 \\
(26.7)\end{array}$ & $\begin{array}{c}08 \\
(50.0)\end{array}$ & $\begin{array}{c}08 \\
(50.0)\end{array}$ & - & $\begin{array}{c}13 \\
(81.3)\end{array}$ & $\begin{array}{c}03 \\
(18.8)\end{array}$ & $\begin{array}{c}03 \\
(18.8)\end{array}$ & $\begin{array}{c}13 \\
(81.3)\end{array}$ & - & - & $\begin{array}{c}13 \\
(81.3)\end{array}$ & $\begin{array}{c}03 \\
(18.8)\end{array}$ \\
\hline MBH & $\begin{array}{c}23 \\
(35.4)\end{array}$ & $\begin{array}{c}08 \\
(34.8)\end{array}$ & $\begin{array}{c}12 \\
(52.2)\end{array}$ & $\begin{array}{c}03 \\
(13.0)\end{array}$ & $\begin{array}{c}20 \\
(87.0)\end{array}$ & $\begin{array}{c}03 \\
(13.0)\end{array}$ & $\begin{array}{c}10 \\
(43.5)\end{array}$ & $\begin{array}{c}10 \\
(43.5)\end{array}$ & $\begin{array}{c}03 \\
(13.0)\end{array}$ & - & $\begin{array}{c}20 \\
(87.0)\end{array}$ & $\begin{array}{c}02 \\
(08.7)\end{array}$ \\
\hline
\end{tabular}

Table 4: SF=Serum Ferritin, ST=Serum Transferrin and SI=Serum Iron, WBC $=$ White blood cell count Low SF $=<20$ ug/), Normal SF $=20-200$ ug/l, High SF $=>200$ ug/l, Low ST $=<200 \mathrm{mg} / \mathrm{dl}$, Normal ST $=200-360 \mathrm{mg} / \mathrm{dl}$, High ST $=>360 \mathrm{mg} / \mathrm{dl}$, Low SI $=<9.0$ umol/l, Normal SI $=9-30.4 \mathrm{umol} / \mathrm{l}, \mathrm{High} \mathrm{SI}=>30.4 \mathrm{umol} / \mathrm{l}$, Low WBC $=<4 \times 10^{9} / \mathrm{l}$, Normal WBC $=4.0-10.0 \times 10 \%$, High WBC $=>10.0 \times 10 \%$. None was registered with Normal ST. (Fortress Diagnostics ISO 13485 Accredited Company).

\begin{tabular}{|c|c|c|c|c|c|c|}
\hline & CDC Tiko & BIH & GHCM & MBH & BRH & Pooled \\
\hline $\mathbf{R}^{2}$ & $66 \%$ & $74 \%$ & $78 \%$ & $69 \%$ & $83 \%$ & $88 \%$ \\
\hline F-Ratio & 8.73 & 14.1 & 16.6 & 10.4 & 22.1 & 52.3 \\
\hline Degree of Freedom & $4: 11$ & 0.221 & 0.208 & 0.2118 & 0.21 & $4: 34$ \\
\hline Critical Value & 3.8 & 2.6 & 2.5 & 2.4 & 2.4 & 6.3 \\
\hline Judgement & s & $\mathrm{S}$ & S & s & $\mathrm{S}$ & S \\
\hline Variable & PM1 & PM1 & PM1 & PM1 & PM1 & PM1 \\
\hline SF & $\begin{array}{c}-0.17 \\
(-1.99)^{+* *}\end{array}$ & $\begin{array}{c}-0.14 \\
(-7.49)^{*}\end{array}$ & NA & $\begin{array}{c}-0.46 \\
(-2.14)^{*}\end{array}$ & $\begin{array}{c}-0.19 \\
(-2.97)^{*}\end{array}$ & $\begin{array}{c}-0.47 \\
(-2.63)^{*}\end{array}$ \\
\hline ST & $0.04(1.78)^{* \star \star \star}$ & $0.04(2.73)^{\star}$ & NA & $0.05(2.45)^{*}$ & $0.64(6.67)^{\star}$ & $0.38(2.20)^{* *}$ \\
\hline SI & $\begin{array}{c}-0.08 \\
(-1.78)^{+* * *}\end{array}$ & $\begin{array}{c}-0.11 \\
(-2.44)^{*}\end{array}$ & NA & $-0.0(-0.58)$ & $\begin{array}{c}-0.0 \\
(-2.21)^{* *}\end{array}$ & $\begin{array}{c}-0.34 \\
(-3.94)^{*}\end{array}$ \\
\hline \multirow[t]{2}{*}{ WBC } & $-0.13(-1.99)$ & $0.02(1.84)$ & NA & $-0.04(-1.63)$ & $0.08(2.67)$ & $0.42(3.33)$ \\
\hline & PM2 & PM2 & PM2 & PM2 & PM2 & PM2 \\
\hline SF & $\begin{array}{c}-0.03 \\
(-1.94)^{* * *}\end{array}$ & $\begin{array}{c}-0.63 \\
(-6.43)^{*}\end{array}$ & $\begin{array}{c}-0.49 \\
(-2.21)^{* *}\end{array}$ & $\begin{array}{c}-0.38 \\
(-2.72)^{*}\end{array}$ & $\begin{array}{c}-0.33 \\
(-1.84)^{+* *+}\end{array}$ & $-0.67(-4.73)^{*}$ \\
\hline ST & $0.56(3.40)^{*}$ & $0.39(2.59)^{*}$ & $0.16(2.76)^{*}$ & $0.34(3.34)^{*}$ & $0.22(1.99)^{* * *}$ & $0.49(3.32)^{*}$ \\
\hline SI & $-0.43(-7.31)^{*}$ & $-0.39(-2.79)^{\star}$ & $\begin{array}{c}-0.66 \\
(-3.15)^{*}\end{array}$ & $-0.39(-2.23)^{* *}$ & $-0.84(-7.34)^{*}$ & $-0.34(-2.33)^{* *}$ \\
\hline WBC & $0.23(2.41)$ & $0.06(1.79)$ & $0.23(3.56)$ & $0.43(3.44)$ & $0.65(1.98)$ & $0.56(3.03)$ \\
\hline
\end{tabular}

Table 5: The quantitative regression results of the effect of malaria on serum ferritin, transferrin and iron, by trimesters.

results are consistent with their correspondent F-ratio values, taking into consideration their degrees of freedoms which are all significant at $\mathrm{P} \leq 0.05$.

Considering the study area as a whole, one percent increase in trophozoites $/ \mu$ l of blood in the second and third trimesters of pregnancy accounted for 0.47 and 0.67 percents decrease in serum ferritin respectively, at $\mathrm{P} \leq 0.01$.

One percent increase in trophozoites/ul of blood during the third trimester of pregnancy accounted for; $0.03 \%$ decrease in serum ferritin in CCT at $\mathrm{P} \leq 0.1 ; 0.49 \%$ decrease in serum ferritin in GHCM at $\mathrm{P}$ $\leq 0.05 ; 0.33 \%$ decrease in serum ferritin in $\mathrm{BRH}$ at $\mathrm{P} \leq 0.1 ; 0.38 \%$ decrease in serum ferritin in $\mathrm{MBH}$ and $0.63 \%$ decrease in serum ferritin in $\mathrm{BIH}$, both at $\mathrm{P} \leq 0.01$. Under steady state conditions serum ferritin level correlates with total body iron stores, therefore decrease in ferritin levels indicates a decrease in iron storage associated with iron deficiency anaemia. But in areas of widespread infection or inflammation, defining iron deficiency using serum ferritin is difficult, as with the case of acute phase proteins, ferritin levels may be artificially high in cases of anaemia of chronic disease, where ferritin is elevated in its capacity as an acute phase protein. The expectation is therefore that serum ferritin in this study with the presence of malaria should act as an acute phase protein and therefore be elevated, with elevation persisting for several days or weeks. But this study considered the insidious effect of malaria infections in the second and third trimester, on serum ferritin levels measured at least one month after testing for malaria in the third trimester of pregnancy. Considering the fact that; parasitaemia was more endemic during the second trimester $(30.8 \%)$ than the third $(23.3 \%) ; 30.8 \%$ of the infected cases had consistent infections (infections in both trimesters), the decrease in serum ferritin 
has been statistically proven to be accounted for by an accumulated/ insidious effect of malaria over time. This effect could be supported by the fact that malaria parasites in red blood cells makes use of the available iron which is replenished from the iron stored forms, resulting to a negative effect on the iron stored forms, and more so in pregnant women with a higher demand for iron, both the development of the fetus and the mother. The result is in contrast with an assessment of iron status of 3605 school children in Zanzibar by Stoltzfus et al. [12]. In this assessment, serum ferritin concentration rose by $1.5 \mu \mathrm{g} / \mathrm{L}$ per 1000 parasites/uL of parasite densities greater than 1000 parasites/uL of blood. The difference might have been due to the different study groups as school children had increase in serum ferritin levels with increase parasites/uL of blood as against the pregnant women who had decrease serum ferritin levels with increase in trophozoites $/ \mu \mathrm{L}$ of blood. Pregnant women have additional need for iron sources of which serum ferritin is a chief source of stored iron. The result of this study is in line with a cross-sectional study carried out by Mockenhaupt et al. in which 530 pregnant women in Ghana was studied, and ferritin levels were considerably influenced by malaria infection [13]. Unlike the study of school children, the study of pregnant women agrees with the present study.

The quantitative results on Table 5 revealed that in general, malaria acquired during the second trimester, had a positive effect on serum transferrin in all the study Centres. Considering the study area as a whole, one percent increase in trophozoites/ $\mu$ l of blood during the second trimester of pregnancy accounted for 0.38 percent increase in serum transferrin and 0.49 percent increase in serum transferrin was accounted for by one percent increase in trophozoites/ $\mu$ l of blood during the third trimester, at $\mathrm{P} \leq 0.01$. It reveals that one percent increase in trophozoites/uL of blood during the second trimester of pregnancy accounted for; 0.04 percent increase in serum transferrin in the CDC Central Clinic at $\mathrm{P} \leq 0.1 ; 0.04$ percent increase in serum transferrin in $\mathrm{BIH}$ at $\mathrm{P} \leq 0.01 ; 0.05$ percent increase in serum transferrin in $\mathrm{MBH}$ at $\mathrm{P} \leq 0.01$, and 0.64 percent increase in serum transferrin in $\mathrm{BRH}$ at $\mathrm{P} \leq 0.01$. In the third trimester one percent increase in trophozoites/ $\mathrm{uL}$ of blood accounted for; 0.56 percent increase in serum transferrin in CCT; 0.16 percent increase in serum transferrin in GHCM; 0.39 percent increase in serum transferrin in $\mathrm{BIH} ; 0.34$ percent increase in serum transferrin in the $\mathrm{MBH}$ at $\mathrm{P} \leq 0.01$ and 0.22 percent increase in serum transferrin in the $\mathrm{BRH}$ at $\mathrm{P} \leq 0.1$.

The normal expectation is that the concentration of transferrin increases to two or three times normal when anaemia is present, but the rise occurs only after iron stores become functionally depleted, whereas serum ferritin concentrations fall earlier, as iron stores fall [14]. As expected, while the presence of malaria had a negative impact on serum ferritin values, it had a positive impact on serum transferrin. Increase in serum transferrin during the third and second trimesters is an indicator of the body's need for iron. This study is in disagreement with the work of Rusia et al. in which serum ferritin measurements in pregnant women did not reflect the true prevalence of iron deficiency [15]. It was concluded in that study that serum transferrin receptor estimation is a more useful measure for detecting iron deficiency in pregnancy, than serum ferritin. In the same vein, Brian et al. reported that serum transferrin levels are a very sensitive means of assessing iron status, and particular in early tissue iron deficiency they reported that it reflects the adequacy of iron supply to cells in general [14]. The results therefore prove that serum ferritin as well as serum transferrin had been good indicators for iron deficiency, as a result of the presence of malaria infection.

Looking at the effects of malaria infections on serum iron, during the third trimester of pregnancy, the quantitative results reveal that one percent increase in trophozoites/uL of blood accounted for; 0.43 percent decrease in serum iron in CCT; 0.39 percent decrease in serum iron in $\mathrm{BIH} ; 0.66$ percent decrease in serum iron in GHCM; 0.84 percent decrease in serum iron in $\mathrm{BRH}(\mathrm{P} \leq 0.01)$ and 0.39 percent decrease in serum iron in $\mathrm{MBH}$ at $\mathrm{P} \leq 0.05$. It can be concluded from the quantitative regression results that, one percent increase in trophozoites/uL of blood in the second trimester of pregnancy accounted for 0.34 percent fall in serum iron in the pregnant women of the Buea and Tiko Health Districts, at $\mathrm{P} \leq 0.01$ and one percent increase in trophozoites/uL of blood during the third trimester, accounted for 0.34 percent decrease in serum iron, at $\mathrm{P} \leq 0.05$.

Considering the negative effects of malaria on iron stores and the insignificant correlation between malaria and the red blood cell indices in the study area in general, it may be inferred that, the values of the red blood cell indices, haematocrit and red blood cell counts were insignificantly affected by malaria. This is probably because iron storage forms (serum ferritin, transferrin and iron) had not been depleted, but significantly affected.

\section{Acknowledgement}

Acknowledgement goes to God Almighty, who guided this study from conception to completion. Special thanks are equally accorded to my supervisors Pr. Monday Francis, Useh and Professor A.A. Alaribe of the University of Calabar. The administration and all the workers of the four study centers who were part of this study are also appreciated. Mr. Nyingchu Robert Vuchuh, Mr. Nfor Edwin Njingti and Professor Njimanted Godfrey Forgha are appreciated for their great contributions to the success of this study.

\section{References}

1. Hastka J, Lasserre JJ, Schwarzbeck A, Strauch M, Hehlmann R (1993) Zinc protoporphyrin in anemia of chronic disorders. Blood 81: 1200-1204.

2. Brabin BJ, Hakimi M, Pelletier D (2001) An analysis of anemia and pregnancyrelated maternal mortality. J Nutr 131: 604S-614S

3. Meier PR, Nickerson HJ, Olson KA, Berg RL, Meyer JA (2003) Prevention of iron deficiency anemia in adolescent and adult pregnancies. Clin Med Res 1 29-36.

4. Wanji S, Tanke T, Atanga SN, Ajonina C, Nicholas T, et al. (2003) Anopheles species of the Mount Cameroon Region: biting habits, feeding behavior and entomological inoculation rates. Tropical Medicine and International Health 8 : 643-649.

5. Wanji S, Kimbi HK, Eyong JE, Tendongfor N, Ndamukong JL (2008) Performance and usefulness of the Hexagon rapid diagnostic test in children with asymptomatic malaria living in the Mount Cameroon region. Malar J 7: 89 .

6. Uzoagulu M (1998) Fundamentals of Statistics. Churchill, United States.

7. Regional Delegation of Public Health (2010) South West Region.

8. WHO. Export Committee on Malaria (2000) Technical Report Series 892 Geneva, World Health Organisation.

9. Meeusen EN, Bischof RJ, Lee CS (2001) Comparative T-cell responses during pregnancy in large animals and humans. Am J Reprod Immunol 46: 169-179.

10. Achidi EA, Kuoh AJ, Minang JT, Ngum B, Achimbom BM, et al. (2005) Malaria infection in pregnancy and its effects on haemoglobin levels in women from a malaria endemic area of Fako Division, South West Province, Cameroon. J Obstet Gynaecol 25: 235-240.

11. Clerk CA, Bruce J, Greenwood B, Chandramohan D (2009) The epidemiology of malaria among pregnant women attending antenatal clinics in an area with intense and highly seasonal malaria transmission in northern Ghana. Tropical Medicine and International Health 1: 4-6.

12. Stoltzfus RJ, Chwaya HM, Albonico M, Schulze KJ, Savioli L, et al. (1997) Serum ferritin, erythrocyte protoporphyrin and hemoglobin are valid indicators of iron status of school children in a malaria-holoendemic population. J Nutr 127: 293-298.

13. Mockenhaupt FP, Rong B, Günther M, Beck S, Till H, et al. (2000) Anaemia in pregnant Ghanaian women: importance of malaria, iron deficiency, and haemoglobinopathies. Trans R Soc Trop Med Hyg 94: 477-483. 
Citation: Nlinwe NO (2014) Effects of Malaria on Iron Stores in the Pregnant Women of Buea and Tiko Health District, South West Region, Cameroon. J Metabolic Synd 3: 170. doi:10.4172/2167-0943.1000170

14. Alper BS, Kimber R, Reddy AK (2000) Using ferritin levels to determine irondeficiency anemia in pregnancy. J Fam Pract 49: 829-832.
15. Rusia U, Flowers C, Madan N, Agarwal N, Sood SK, et al. (1999) Serum transferrin receptors in detection of iron deficiency in pregnancy. Ann Hematol 78: $358-363$ 